\title{
A novel framework for integrating social media as cooperative learning tool in higher education's classrooms
}

\author{
Mostafa Hamadi ${ }^{*}$ D, Jamal El-Den, Sami Azam and Narumon Cherry Sriratanaviriyakul
}

\author{
*Correspondence: mostafahamadi@ \\ outlook.com \\ Charles Darwin University, \\ Ellengowan Dr, Casuarina, Darwin, \\ NT 0810, Australia
}

\begin{abstract}
Despite the considerable body of literature on social media (SM)'s use as formal educational tools within universities, little has been done to provide a comprehensive adoption framework for SM as cooperative learning $(\mathrm{CL})$ instruments. Nonetheless, the pedagogical arguments for SM's use in HE have theory support. This paper proposes an original SM integration framework based on CL methods within higher education (HE). An integrative review of relevant literature followed by a thematic review of six peer-reviewed empirical research and a thorough examination of relevant SM adoption models are conducted to identify commonalties and themes. In total, six themes were identified and incorporated as major components in the proposed framework. To the best of our knowledge, no previous research has proposed a framework that incorporates $C L$ principles to support an effective SM integration process in HE. This paper proposes a novel integration framework which is a theoretically driven pedagogical guide for incorporating SM in HE's classrooms. It provides valuable insights on SM's use in education and forms the basis for future quantitative and qualitative (framework-testing) research in this area of study.
\end{abstract}

Keywords: Social media, Higher education, Cooperative learning, Pedagogical framework, Integration framework

\section{Introduction}

The emergence of web 2.0 technologies instigated major change not only in course delivery approaches in higher education (HE) but also in pedagogical practices adopted by universities. Today, learning management systems (LMS) such as "Blackboard Learn" are indispensable parts of universities' classrooms and that is not limited to universities in developed countries. Current researchers such as Junco (2012) have emphasized the changes in HE's learning environments, namely, the shift from concentrating on knowledge skills into highlighting long-learning in terms of skills such as collaboration skills. As Bransford et al. (2000) puts it, "a fundamental tenet of modern learning theory is that different kinds of learning goals require different approaches to instructions" (p. 131). Hence, innovative learning approaches such as integrating SM in HE is necessary to address the changes in HE's settings especially in creating learnercentered classrooms.

(c) The Author(s). 2021 Open Access This article is licensed under a Creative Commons Attribution 4.0 International License, which permits use, sharing, adaptation, distribution and reproduction in any medium or format, as long as you give appropriate credit to the original author(s) and the source, provide a link to the Creative Commons licence, and indicate if changes were made. The images or other third party material in this article are included in the article's Creative Commons licence, unless indicated otherwise in a credit line to the material. If material is not included in the article's Creative Commons licence and your intended use is not permitted by statutory regulation or exceeds the permitted use, you will need to obtain permission directly from the copyright holder. To view a copy of this licence, visit http://creativecommons.org/licenses/by/4.0/. 
Integrating SM in HE classrooms is part of the researchers and practitioners' ongoing initiatives to address changes in HE's classrooms (Kaplan and Haenlein 2016). Moreover, SM's use in education has long been associated with specific pedagogical approaches, namely, constructivist-based approaches such as cooperative learning (CL) (Chugh and Ruhi 2018). Though the relationship between SM and CL has not yet been clarified, hence, it is not obvious how SM can be employed to achieve CL objectives within HE settings.

Recent scholars such as Al-Rahmi et al. (2018), Rahman et al. (2020), and Stathopoulou et al. (2019) suggested more studies were needed to address the issue of effective SM integration in HE. Previous work such as Mnkandla and Minnaar (2017) has been limited to self-reported isolated studies that examine perceptions and experiences of students and instructors rather than addressing the practicality and effectiveness of SM as an educational tool, i.e., impact on collaborative learning and deep learning. To the best of our knowledge, there are no other studies that propose a standard SM integration framework to support CL within HE classrooms. The absence of such framework contributes to the growing number of self-reported studies in this area of research. The proliferation of studies that examines SM's use in HE lacks direction for the implementation of findings. Thus, it is necessary to synthesize the knowledge generated in this field to develop a comprehensive integration framework that facilitates the implementation of SM in HE classrooms. Yet, an intriguing question arises here:

- (RQ1) Is there any theoretical basis for integrating SM in HE?

The literature review in this paper starts by addressing this question and extends to address the following research questions.

- (RQ2) How is SM being used as a pedagogical tool in HE?

- (RQ3) Is there any current SM integration framework? How to develop an integration framework for SM's adoption as CL tool in HE's classrooms?

This paper identified several drawbacks in previous research work such as Zheng et al. (2015), Rambe (2017), Menzies et al. (2017), De Wever et al. (2015), and Bagarukayo (2018). These studies examined the adoption of SM to support learning activities in a traditional faceto-face HE classroom and outside classroom hours to supplement offline learning activities. First, current frameworks are based on isolated studies and are not based on the analysis of previous empirical research in this field of study. Secondly, these frameworks, as outlined in section 2.3, do not act as a step-by-step integration guides to SM in HE, but rather as approaches to measure its influence on specific learning aspects such as social learning and deep learning. Lastly, the frameworks fell short in identifying key learning principles, such as CL principles, in their structure; thus, it is not clear how they will ensure an effective SM's integration process that can achieve intended pedagogical objectives. In this paper, the authors conduct an integrative review to examine how to develop an adoption framework for SM in HE based on CL. The integrative review addresses the following questions, (1) What experimental research are available that focus on SM's use as formal educational tools in support of CL approaches within HE? (2) How researchers/educators are using SM as CL tool in HE settings (practices)? and (3) What themes do exist among the identified studies? 


\section{Literature review}

\section{Theoretical basis for SM in education}

Implementing SM as learning tool in education settings is driven by the shift toward adopting learner-centered environments within universities (Liburd and Christensen 2013). This approach to teaching and learning (T\&L) sees the instructor as a facilitator of the learning process rather than being the disseminator of knowledge. Nonetheless, this approach comes under the umbrella of active learning, in which the student interacts and participates in the learning process as opposed to passive learning where it is mostly a one-way effort from the learner (Freeman et al. 2014). Current researchers have applied various theories as the theoretical basis for SM's integration in HE. The adopted theories include active learning theories such as uses and gratification theory (UGT), connectivism and constructivism as well as technology adoption theories such as the technology acceptance model (TAM). These theories are outlined as follows:

A sample of research based on the UGT approach that investigates SM's use in HE along with their major findings is as follows, Ahern et al. (2016), Corcuera (2019), Gruzd et al. (2018), and Musa et al. (2015). Ahern et al. (2016) concluded that the attributes of "Facebook" lead to interaction. Thus, satisfying the higher-level information and decision-making needs of students (Ahern et al. 2016). Corcuera (2019) found that educators in the selected HE institutions use SM to provide human needs, namely, cognitive, affective, personal integrative, integration and social interaction, and escapism. In addition, Gruzd et al. (2018)'s study identified six positive factors which are associated with SM's use in HE teaching, including facilitating student engagement, engagement with outside resources, enhancing student attention to content, instructor's organization for teaching, building communities of practice, and resource discovery. The findings of these studies suggest that SM has the potentials to achieve CL in HE classrooms.

Researchers such as Absar et al. (2016), Goldie (2016), and Ripiye et al. (2017) followed connectivism to investigate SM's integration in HE's classrooms. These studies suggest that SM has the potential to enhance learning when implemented effectively within classrooms. SM plays an important role in creating online learning communities which can promote interaction, participation, and co-construction of knowledge and information among learners (Absar et al. 2016; Goldie 2016; Ripiye et al. 2017).

Furthermore, researchers such as Al-Rahmi et al. (2018), Alenazy et al. (2019), and Arif and Kanwal (2016) used TAM as the theoretical basis to understand SM's impacts in HE. These studies emphasize the potentials of SM as collaborative and engagement tools within HE classrooms. SM supports group discussion, higher engagement, and collaborative learning among HE learners (Al-Rahmi et al. 2018; Alenazy et al. 2019; Arif and Kanwal 2016).

Nonetheless, constructivist-based theories are excessively used by researchers to investigate SM in HE. Constructivism suggests that learners construct their own understandings, thereby developing knowledge for themselves (Bereiter 1994; Hein 1991). In essence, learners construct or reconstruct knowledge in terms of their already existing knowledge base, thus reconciling new information with their previous ideas and experiences to form new or enhanced understanding (Bransford et al. 2000). Constructivism emphasizes the social aspect of learning. Consequently, learning happens primarily though interaction with others such as in classroom 
settings (Kivunja 2014). A prime example of this can be seen in Kagan's Timed Pair Share in which students are allocated in pairs and take turns in speaking for a specified time. Then, each student receives feedback from their team member to ensure equal contribution happens (Kagan and Kagan 1998). A sample of major research that is based on constructivist-based approaches to investigate SM's use in HE is as follows: Akçayrr (2017), Ansari and Khan (2020), and Kivunja (2014). Other forms of constructivism such as online collaborative learning theory $(\mathrm{OCL})$ and $\mathrm{CL}$ are gaining robust momentum in this field of study.

$\mathrm{CL}$ is a well-established constructivist pedagogy that is gaining great potentials for HE. Johnson et al. (1994) defines CL as the "instructional use of small students' groups for them to work together and maximise their individual as well the group's overall learning" (p. 3). This approach to learning is based on Lewin (1938) and Deutsch (1949)'s theories of social interdependence. Thus, CL is based fundamentally on the concept that developing interpersonal skills is as important as learning itself (Scager et al. 2016). Nonetheless, developing practical methods, i.e., SM activities, based on research-validated theory such as $\mathrm{CL}$, can promise positive outcomes in the intended learning environment (Slavin 2014). Kagan and Kagan (1998) summarizes the principles of CL in the acronym PIES which is described below.

$\mathrm{P}$-positive interdependence is achieved when students realize that they "sink or swim together" (Kagan and Kagan 1998, p. 225). Accordingly, students in allocated groups share common learning goals and perceive that working together as part of a group will result in benefits for all group members (Johnson et al. 1994).

I-individual accountability: An ever-existing robust challenge to groupwork's effectiveness is social loafing, or "the tendency for individuals to spend less effort when working collectively than when working individually" (Karau and Williams 1993, p. 681). Hence, individual accountability in CL is pivotal to prevent and minimize the occurrence of social loafing in CL groups. Students of the same group must be made aware they will be held accountable for their individual performance and learning.

E-equal participation is reflected in the equal participation of members in the groups' overall work. This can be ensured by following a highly structured teamwork approach such as Kagan's Timed Pair Share which includes structuring time, individual outcomes, and structuring for the equality rather than assigning students into groups and hoping equal contribution happens (Kagan and Kagan 1998).

S-simultaneous interaction: it is assumed that the group's efficiency increases when all members are interacting at the same time. Hence, students in the same group should be exchanging ideas, communicating, interacting, and discussing groupwork at any one time or simultaneously (Kagan and Kagan 1998). Accordingly, simultaneous interactions can be achieved by adopting SM which incorporates innovative technologies that allows real-time simultaneous interactions between its users. These technologies' features include instant messaging, commenting, reactions (i.e., emojis), and others.

Nonetheless, these SM features can also support online asynchronous interactions between users. Researchers such as Rosenberg et al. (2017) stated that SM platforms support both synchronous and asynchronous online interactions at the same time. Thereby, depending on the learning activities and strategies, educators can use SM to conduct online asynchronous interactions to enhance students' learning outcomes (Kebble 2017). 


\section{SM's pedagogical usage within $\mathrm{HE}$}

SM's adoption is not limited to one academic discipline, though it was most notably used in literacy education, medical, marketing, and social sciences disciplines. SM's use in academic disciplines was predominantly associated with aims to promote information sharing, enhancing interaction and engagement, boosting collaboration and cooperation, and supporting general-life satisfaction for the concerned practitioners, learners, and/or academic staff (Brown et al. 2016; Greenhow and Burton 2011; Gruzd et al. 2018) albeit it is noted that SM's adoption for educational use was significantly high in courses that put more importance on practice (training) rather than theory. For example, in medical education where it is being as part of student-centered learning approaches such as flipped classrooms, cooperative and collaborative learning methods (Alenazy et al. 2019; Chung et al. 2019; Dyson and Casey 2016). Though many researchers remained skeptical of SM's use and impact on users in education settings and have raised several concerns, these concerns were identified as major challenges or resistance to SM's inclusion in academic disciplines as seen in Table 1.

\section{Current SM integration frameworks in $\mathrm{HE}$}

Most research on SM in HE provides recommendations and lessons learned rather than a comprehensive guide to SM's inclusion in HE. Hence, the current research appears more appropriate for policymakers and practitioners seeking to learn more about how SM could influence students' learning process or their access to education. The need for a comprehensive SM integration framework which incorporates principles from relevant learning theories such as constructivism is more than ever needed. Few researchers have addressed this issue.

In Al-rahmi et al. (2015)'s framework, the authors' work focused on linking theory (constructivism and TAM) with practice (SM adoption), thus establishing solid theoretical basis for SM's inclusion in HE classrooms. However, their framework is primarily based on a self-reported method. The authors used results from a survey completed by $323 \mathrm{HE}$ students to propose a SM adoption framework in HE. Nevertheless, this framework did not provide a clear SM integration approach which includes chronological steps and guidelines for educators to follow.

Mnkandla and Minnaar (2017)'s proposed framework was founded on Harasim (2012)'s OCL theory's three phases: idea generating (IG), idea organizing (IO), and intellectual convergence (IC). The focus of this framework was to facilitate SM's adoption as a deep learning strategy in HE. Despite the authors' acknowledgement of the changes of learning goals in $\mathrm{HE}$, especially the move toward more integrative or collaborative

Table 1 Common findings of SM's challenges and drawbacks in education

\begin{tabular}{|c|c|}
\hline $\begin{array}{l}\text { SM's challenges and } \\
\text { drawbacks }\end{array}$ & Sources \\
\hline 1. Personal privacy & Alkis et al. (2017), Au and Lam (2015), and Chugh and Ruhi (2018) \\
\hline 2. Ambiguity concerns & Balakrishnan (2017), Fenwick (2016), and Novakovich et al. (2017) \\
\hline 3. Technical barriers & Bahati (2015), Harran and Olamijulo (2014), and Sobaih et al. (2016) \\
\hline 4. Workload concerns & $\begin{array}{l}\text { Junco and Cotten (2012), Pearce and Learmonth (2016), and Rowan-Kenyon and } \\
\text { Alemán (2016) }\end{array}$ \\
\hline
\end{tabular}


learning approach in the digital age, their proposed framework did not address key elements of collaborative learning such as CL principles.

In a book titled "Using social media in the classroom: A best practice guide," Poore (2015) provided an extensive guide to integrate SM in classrooms. Although Poore (2015)'s guide provided a step-by-step approach to integrate major SM platforms in general classrooms, her focus was not on HE classroom settings. Poore (2015)'s book is to our knowledge the most notable best practice guide available in current literature. However, the book did not specify a standard framework for SM's inclusion in HE's T\&L practices. Nonetheless, Poore (2015)'s guide described sensitive aspects of SM's use in education such as privacy concerns and control and monitoring issues.

Other prominent researchers such as Conway et al. (2011), Foroughi (2011), and Zotos and Armakolas (2018) identified major factors to be considered when examining SM's integration in HE including university factors, instructors' capabilities, and students' specifications. Foroughi (2011) puts forward several variables that are most likely to impact SM's integration initiatives in universities at three levels, macro, mezzo, and micro levels based on an analysis of more than 15 peer-reviewed studies. Foroughi (2011)'s research framework provides a clear set of variables that can guide future research on SM's integration in HE. Factors requiring further examination according to Foroughi (2011) are SM challenges including workload concerns, ambiguity and privacy concerns, faculty incentives, collaborative initiatives, and scaffolding of Web 2.0 in the course.

\section{Emerging themes from the literature}

Three themes emerged from examining the above sources and are described below. These themes are highly valuable for the development of an effective SM integration framework and were incorporated as such in this paper's proposed framework (Fig. 2).

\section{Developing an adoption framework based on a relevant pedagogical approach}

It is vital for the SM implementation process to be well-founded on an appropriate pedagogical approach in HE (Al-Rahmi et al. 2018; Alenazy et al. 2019; Ansari and Khan 2020; Goldie 2016; Musa et al. 2015; Slavin 2014). The inclusion of pedagogical methods and elements, such CL principles, in the framework will ensure the achievement of the intended learning objectives (Mnkandla and Minnaar 2017; Slavin 2014). Considering that SM is especially associated with constructivism, namely, CL, it is important to specify how the integration framework will address key CL principles and objectives (Ansari and Khan 2020; Lam 2015). An effective approach would be to incorporate major CL principles within the phases of the framework.

\section{Mitigating challenges associated with SM in education}

For a successful implementation process, it is essential to control major risks and challenges associated with SM in education as found by the sources listed in Table 1. SM's challenges in education such as privacy and ambiguity concerns should be adequately controlled or minimized to promote its utilization by faculty (Alkis et al. 2017; Au and 
Lam 2015; Chugh and Ruhi 2018; Foroughi 2011; Poore 2015). An effective integration framework must include clear guidelines to address major SM challenges in HE.

\section{Evaluating the integration process}

Evaluating the integration process is vital for various reasons. Primarily, it aims to assess the overall quality and effectiveness of the integration process and provides decision-makers with valuable insights for improvements. In addition, it is used to gather constructive feedback and reflections on the process so shortfalls can be avoided in the future (Al-Rahmi et al. 2018; Foroughi 2011; Zotos and Armakolas 2018).

\section{Research methods}

This paper adopts an integrative review as a principal research method. This method allows the analysis of findings from a heterogeneous research sample which includes various research methodologies. Hence, an integrative review suits the objectives of this paper which intends to examine diverse approaches used by researchers and practitioners to integrate SM in support of CL in HE classrooms. In order to enhance the rigor of the process, this paper adapts Whittemore and Knafl (2005)'s five methodological stages, including problem identification, literature search, data evaluation, analysis, and presentation.

\section{Search method}

Accessed through an online library, six databases were used in searching the literature, namely, Scopus, Education Research Complete, Springer link, IEEE Xplore - digital library, Emerald fulltext, and PubMed. The authors used various combinations of Boolean phrases/keywords to search the databases, illustrated as follows:

(1) (ALL ("Cooperative learning”) AND TITLE-ABS-KEY (“Social media”) AND ("higher education")

(2) AB cooperative learning AND social networking AND higher education

(3) cooperative learning "social media" OR web 2.0 OR social network" OR twitter OR facebook OR Linkedin OR whatsapp

(4) (content-type: article) AND (abstract: "cooperative learning" AND (social media))

(5) (cooperative learning [Title/Abstract]) AND (social media [Title/Abstract])

Only studies written in English and published between 2015 and 2020 were included. Sources such as commentaries, letters to editors, dissertations, monographs, and literature reviews were excluded from the initial search. The initial search resulted in 136 articles excluding secondary research to be screened for inclusion in the integrative review. As evident, the initial search shows that SM's inclusion as a CL tool in HE classroom is in its infancy with more research are yet to surface.

The search methods used in this study were adapted from PRISMA as reflected in Fig. 1 (Moher et al. 2015). Out of the initial 136 identified articles, 89 were excluded by title, abstract, and aims. Furthermore, 41 articles were eliminated by applying the eligibility criteria shown in Table 2 . 


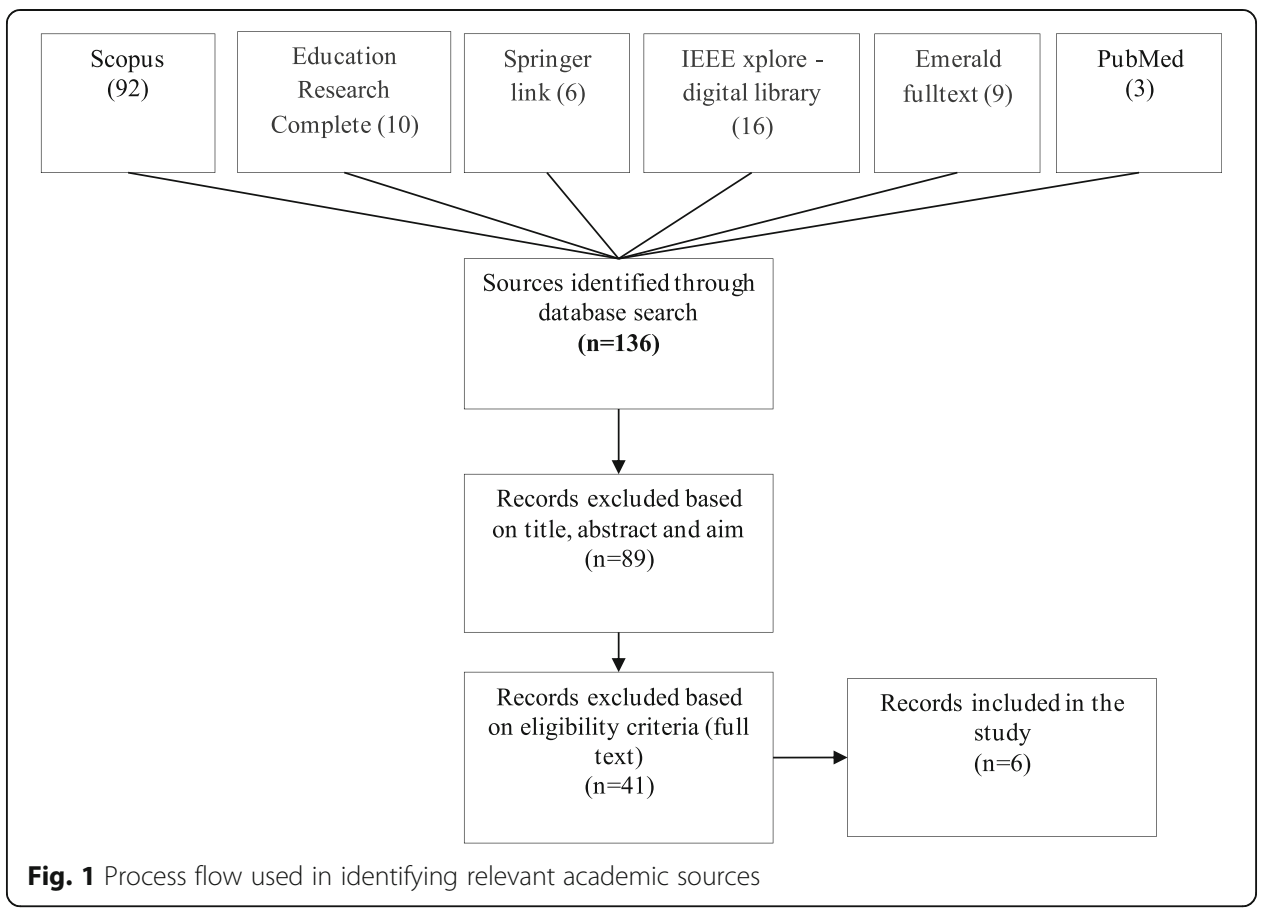

\section{Selection criteria}

To ensure the inclusion of most relevant research in this review, the search included studies performed on SM platforms such as Facebook, twitter, LinkedIn, and WhatsApp. Papers conducted on social learning networks (SLNs) such as Edmodo and others were excluded from the initial search. In order to ensure trustworthiness of the review and to further assess the quality of sampled articles, the authors developed an eligibility criteria list, which was adapted from Gersten et al. (2005)'s essential quality indicator for group experimental research. The 10 essential quality indicators were adopted as the review aims to include only practical examples, i.e., experimental designs, on how SM is being used within HE classroom to support CL. Hence, studies which are founded on experimental research designs were solely included in the research sample (Table 3). This rigorous process of screening and exclusion resulted in the inclusion of 6 most relevant peer-reviewed research, which were selected for the integrative review. The sampled sources involved experiments on different SM platforms. In total, 3 platforms were studied by selected papers as seen below in Table 3.

\section{Results and discussion}

\section{Analysis of sampled studies}

In order to find out what studies currently exist on SM's use as formal educational tools in HE's settings to support CL approaches, the sampled studies were analyzed, and data were presented in Table 4. These studies examined the use of SM during class hours as well as out of class hours as indicated in Table 4. Data on each source including year of publication, location, targeted courses, sample size, findings, and SM integration practices were displayed. In addition, Table 4 addresses the question of "how researchers and educators are using SM as CL tool in HE settings?" by presenting a 
Table 2 The eligibility criteria list adapted from (Gersten et al. 2005)

Essential quality indicators
1. Is the conceptualization based on well-designed studies and does it reflect the scope of extant
knowledge?
2. If an innovative approach is proposed, is it based on a sound conceptualization formed from sound
research?
3. Are the research questions appropriate and stated clearly for the purposes of this study? Are valid
arguments supporting the nature of intervention in the comparison group(s) presented?
4. Will appropriate procedures be used to ensure that participants are comparable across intervention
conditions on relevant characteristics?
5. Is the intervention clearly described?
6. Are procedures for ensuring and assessing fidelity of implementation described?
7. Is the nature of instruction provided in comparison conditions described?
8. Is evidence of reliability for the outcome measures provided? If not, will it be calculated?
9. Are the data analysis techniques appropriate and linked to key research questions and hypotheses?
10. Were outcomes for capturing the intervention's effect measured at the appropriate times?

summary of how researchers are using SM as part of CL in HE settings under the employed practices column.

\section{Emergent themes from the analysis of sampled articles}

To find out what themes exist among the identified studies, this paper adapted Braun and Clarke (2006)'s six-phase guide to conduct a thematic review on the tabulated data in Table 4. The six-phase guide includes familiarization with the data, generating initial codes, searching for themes, reviewing themes, defining and naming themes, and producing the report (Braun and Clarke 2006). Three themes emerged from the thematic review of sources and are identified below.

\section{Developing clear measures and guidelines for students}

It is essential for instructors to develop clear measures and guidelines for students to ensure a successful SM integration process as reported by De Wever et al. (2015), Menzies et al. (2017), and Zheng et al. (2015). Students need to be made aware of why they are using the SM platform? What is expected from them? and How they will be using it for educational purposes? Addressing these three questions through a clear guide and making it available for students prior to the integration process will positively impact the integration processes. Accordingly, a guide which includes instructions on how to effectively use the SM platform for educational purposes has manifold of benefits. It provides guidance for students throughout the duration of SM's usage. In addition, it sets clear objectives for students to achieve thereby assisting them in

Table 3 Sampled sources with studied SM platform

\begin{tabular}{ll}
\hline SM platforms & Sources \\
\hline Wiki & De Wever et al. (2015) and Zheng et al. (2015) \\
Facebook & Bagarukayo (2018), Chookaew (2015), and Menzies et al. (2017) \\
Google Groups & Rambe (2017) \\
\hline
\end{tabular}


Table 4 The analysis of sources included in the integrative review

\begin{tabular}{|c|c|c|c|c|c|}
\hline Source & $\begin{array}{l}\text { Research } \\
\text { design/ } \\
\text { sample }\end{array}$ & Location/course & $\begin{array}{l}\text { Examined } \\
\text { tool }\end{array}$ & Major practices & Major findings \\
\hline $\begin{array}{l}\text { 1. Zheng } \\
\text { et al. (2015) }\end{array}$ & $\begin{array}{l}\text { Iterative, } \\
\text { design-based } \\
(n=139)\end{array}$ & $\begin{array}{l}\text {-China } \\
\text {-Educational } \\
\text { Technology, History } \\
\text { and Physical } \\
\text { Sciences } \\
\text {-Duration: from Fall } \\
2007 \text { to Fall } 2009 \\
\text { (four-iteration } \\
\text { design-based } \\
\text { research) }\end{array}$ & Wiki & $\begin{array}{l}\text {-Groups by topics } \\
\text { chosen. } \\
\text {-Co-wrote on a single } \\
\text { Wiki page. } \\
\text {-Students signed up } \\
\text { for tasks and each } \\
\text { was explicitly } \\
\text { responsible for a } \\
\text { specific part of the } \\
\text { content creation. } \\
\text {-Students chose a } \\
\text { group leader and } \\
\text { assigned roles and } \\
\text { responsibilities for } \\
\text { each one of them. } \\
\text {-Students discussed, } \\
\text { share resources, and } \\
\text { reflected on } \\
\text { groupwork. } \\
\text {-Instructor provided } \\
\text { examples of prior } \\
\text { student work on wiki. } \\
\text {-Instructor and } \\
\text { researcher played the } \\
\text { roles of facilitators. } \\
\text {-Instructor provided } \\
\text { out-of-classroom sup- } \\
\text { port via email/an- } \\
\text { swering questions on } \\
\text { wiki and used incen- } \\
\text { tives in the third and } \\
\text { fourth activities to } \\
\text { motivate students. }\end{array}$ & $\begin{array}{l}\text {-Well-designed } \\
\text { instruction is vital to } \\
\text { the success of any } \\
\text { technology-facilitated } \\
\text { learning activities in } \\
\text { HE. } \\
\text {-The Wiki project } \\
\text { grew more effective } \\
\text { with several rounds } \\
\text { of iterations. } \\
\text {-Future research } \\
\text { should address the } \\
\text { development of } \\
\text { iterative design } \\
\text { approaches for } \\
\text { refining teaching } \\
\text { strategies. }\end{array}$ \\
\hline $\begin{array}{l}2 . \\
\text { Chookaew } \\
\text { (2015) }\end{array}$ & $\begin{array}{l}\text { Experimental } \\
\text { design with } 2 \\
\text { groups } \\
\text { (including a } \\
\text { control group) } \\
(\mathrm{n}=59)\end{array}$ & $\begin{array}{l}\text {-Thailand } \\
14 \text { weeks } \\
\text {-Computer, } \\
\text { Multimedia } \\
\text { instruction course }\end{array}$ & Facebook & $\begin{array}{l}\text {-Created teams by } \\
\text { topic of individual } \\
\text { interest. } \\
\text {-Students shared } \\
\text { personal information } \\
\text { on the group. } \\
\text {-Students in the } \\
\text { group were held } \\
\text { accountable for the } \\
\text { work completed and } \\
\text { the materials to be } \\
\text { learnt. } \\
\text {-Students discussed } \\
\text { and exchanged ideas } \\
\text { about the } \\
\text { assignment (in/out } \\
\text { class hours). } \\
\text {-Students provided } \\
\text { feedback and } \\
\text { encouraged one } \\
\text { another. } \\
\text {-Instructor provided a } \\
\text { detailed guide of } \\
\text { conditions for } \\
\text { students to work } \\
\text { with. } \\
\text {-The instructor was } \\
\text { the facilitator of } \\
\text { groupwork. }\end{array}$ & $\begin{array}{l}\text {-Online cooperative } \\
\text { learning through } \\
\text { Facebook groups } \\
\text { enhanced students' } \\
\text { learning } \\
\text { achievement. } \\
\text {-Promoted positive } \\
\text { attitudes toward } \\
\text { learning. }\end{array}$ \\
\hline $\begin{array}{l}\text { 3. Rambe } \\
\text { (2017) }\end{array}$ & $\begin{array}{l}\text { Community of } \\
\text { Inquiry and a } \\
\text { case study }\end{array}$ & $\begin{array}{l}\text {-South Africa } \\
\text {-Masters in ICTs in } \\
\text { Education }\end{array}$ & $\begin{array}{l}\text { Google } \\
\text { Groups }\end{array}$ & $\begin{array}{l}\text {-Two students' } \\
\text { administrators } \\
\text { signing new group }\end{array}$ & $\begin{array}{l}\text {-Google Groups } \\
\text { presented multiple } \\
\text { academic }\end{array}$ \\
\hline
\end{tabular}


Table 4 The analysis of sources included in the integrative review (Continued)

\begin{tabular}{|c|c|c|c|c|c|}
\hline Source & $\begin{array}{l}\text { Research } \\
\text { design/ } \\
\text { sample }\end{array}$ & Location/course & $\begin{array}{l}\text { Examined } \\
\text { tool }\end{array}$ & Major practices & Major findings \\
\hline & $\begin{array}{l}\text { approach }(n= \\
15)\end{array}$ & -4 months duration & & $\begin{array}{l}\text { members, regulating } \\
\text { their academic } \\
\text { behavior and blocked } \\
\text { access to non-class } \\
\text { members. } \\
\text {-Group was a } \\
\text { restricted/closed site. } \\
\text {-Student had full } \\
\text { ownership of posts } \\
\text { and group } \\
\text { discussions. } \\
\text {-The educator did } \\
\text { not participate in } \\
\text { discussions and } \\
\text { posts. } \\
\text {-The educator joined } \\
\text { the group and was } \\
\text { only responding to } \\
\text { questions. } \\
\text {-Posts are not } \\
\text { obligatory by } \\
\text { students. } \\
\text {-In/out class hours }\end{array}$ & $\begin{array}{l}\text { engagement } \\
\text { opportunities. } \\
\text {-Benefits were shown } \\
\text { in emergent } \\
\text { academic } \\
\text { networking, student } \\
\text { access to } \\
\text { knowledgeable peers } \\
\text { and academics, and } \\
\text { improved the online } \\
\text { visibility of } \\
\text { interactants } \\
\text {-Issues of } \\
\text { administrators' } \\
\text { dominance over } \\
\text { group members as } \\
\text { well equitable } \\
\text { participation which is } \\
\text { indicative of the } \\
\text { importance of } \\
\text { academic regulation } \\
\text { and incentive. }\end{array}$ \\
\hline $\begin{array}{l}\text { 4. Menzies } \\
\text { et al. (2017) }\end{array}$ & $\begin{array}{l}\text { Case study } \\
\text { research (use } \\
\text { of focus } \\
\text { groups) ( } n= \\
\text { 11) }\end{array}$ & $\begin{array}{l}\text {-Scotland } \\
\text {-The school of } \\
\text { computing } \\
-2 \text { months }\end{array}$ & Facebook & $\begin{array}{l}\text {-The staff member } \\
\text { and tutors are the } \\
\text { administrators } \\
\text { discussing topics } \\
\text { providing and } \\
\text { sharing further online } \\
\text { resources. } \\
\text {-Students answer and } \\
\text { discuss the topics in } \\
\text { a collaborative } \\
\text { manner. } \\
\text {-Staff can step in to } \\
\text { clear out } \\
\text { misunderstandings } \\
\text {-If limited activity in } \\
\text { the group, the staff } \\
\text { member may seed a } \\
\text { conversation. } \\
\text {-Assignment groups } \\
\text { are created and } \\
\text { managed solely by } \\
\text { students. } \\
\text {-Used for } \\
\text { communications } \\
\text { relating to a given } \\
\text { assignment (in/out } \\
\text { class hours). } \\
\text {-Created on an ad } \\
\text { hoc basis and may } \\
\text { be repurposed for } \\
\text { future assignments } \\
\text { where appropriate. }\end{array}$ & $\begin{array}{l}\text {-A blur in SM's uses } \\
\text { and purpose in } \\
\text { education contexts. } \\
\text {-Use of different } \\
\text { purpose groups is } \\
\text { useful as it allows } \\
\text { breaking } \\
\text { communications } \\
\text { down so students } \\
\text { would not be } \\
\text { overwhelmed. } \\
\text {-Familiarity and } \\
\text { usability of Facebook } \\
\text { helped achieve the } \\
\text { positive results. } \\
\text {-Staff moderation of } \\
\text { groups yielded much } \\
\text { discussion. } \\
\text {-Students expected } \\
\text { staff to direct them } \\
\text { to the privacy } \\
\text { settings. }\end{array}$ \\
\hline $\begin{array}{l}\text { 5. De Wever } \\
\text { et al. (2015) }\end{array}$ & $\begin{array}{l}\text { Experimental } \\
\text { design }(n= \\
186)\end{array}$ & $\begin{array}{l}\text { Educational } \\
\text { Sciences } \\
\text {-Three-week period }\end{array}$ & Wiki & $\begin{array}{l}\text {-Participation was } \\
\text { complimentary. } \\
\text {-Students were } \\
\text { randomly assigned to } \\
\text { a group. } \\
\text {-Specific guidelines, } \\
\text { in the form of a step- } \\
\text { by-step plan, were } \\
\text { provided to organize } \\
\text { their group work. }\end{array}$ & $\begin{array}{l}\text {-Scripting (providing } \\
\text { a guide) was } \\
\text { beneficial. } \\
\text {-It increased the } \\
\text { shared responsibility } \\
\text { within a collaborative } \\
\text { environment. } \\
\text {-The script can } \\
\text { influence how } \\
\text { thorough a task is }\end{array}$ \\
\hline
\end{tabular}


Table 4 The analysis of sources included in the integrative review (Continued)

\begin{tabular}{|c|c|c|c|c|c|}
\hline Source & $\begin{array}{l}\text { Research } \\
\text { design/ } \\
\text { sample }\end{array}$ & Location/course & $\begin{array}{l}\text { Examined } \\
\text { tool }\end{array}$ & Major practices & Major findings \\
\hline & & & & $\begin{array}{l}\text {-Students built } \\
\text { knowledge on each } \\
\text { other's work. } \\
\text {-In/out class hours } \\
\text {-Students taking turn } \\
\text { in completing the } \\
\text { drafts and final } \\
\text { deliverable. } \\
\text {-Students edited } \\
\text { others' ideas in Wikis } \\
\text { to increase the } \\
\text { amount of work } \\
\text { shared. }\end{array}$ & dealt with. \\
\hline $\begin{array}{l}6 . \\
\text { Bagarukayo } \\
(2018)\end{array}$ & $\begin{array}{l}\text { Bowers } \\
\text { Affordance } \\
\text { Analysis } \\
\text { eLearning } \\
\text { design } \\
\text { methodology } \\
\text { framework ( } \mathrm{n}= \\
\text { 48) }\end{array}$ & $\begin{array}{l}\text { Makerere University } \\
\text { Uganda } \\
\text { Students at the } \\
\text { Operating Systems } \\
\text { course unit at the } \\
\text { School of } \\
\text { Computing and } \\
\text { Informatics } \\
\text { Technology }\end{array}$ & Facebook & $\begin{array}{l}\text {-A closed group page } \\
\text { in Facebook was } \\
\text { created. } \\
\text {-Students did all } \\
\text { discussions, } \\
\text { commented on } \\
\text { posts, posted videos, } \\
\text { links, uploaded and } \\
\text { shared videos they } \\
\text { created. } \\
\text {-In/out class hours } \\
\text {-Multimedia content, } \\
\text { such as videos, } \\
\text { music, pictures, text, } \\
\text { and emojis, were } \\
\text { used as posts } \\
\text {-Access to group } \\
\text { page required } \\
\text { approval from the } \\
\text { administrator and } \\
\text { creator of group }\end{array}$ & $\begin{array}{l}\text {-The group enabled } \\
\text { peers' interactions, } \\
\text { critiquing and } \\
\text { learning from one } \\
\text { another in the } \\
\text { process. } \\
\text {-Facebook affords } \\
\text { students ability to } \\
\text { communicate, } \\
\text { interact, and } \\
\text { collaborate. } \\
\text {-Students were } \\
\text { actively engaged and } \\
\text { enjoyed the use of } \\
\text { Facebook to learn. }\end{array}$ \\
\hline
\end{tabular}

developing a work plan or a group plan with clear set of tasks and objectives (Chookaew 2015; De Wever et al. 2015; Menzies et al. 2017; Zheng et al. 2015).

Developing incentives to encourage students' participation in SM activities

Evidently, using incentives to encourage students to participate in the learning activities though SM is pivotal in the integration process. The inclusion of a reward system alongside the implementation process would motivate students to participate and engage more in the proposed SM learning activities as identified in the examined researches by Rambe (2017) and Zheng et al. (2015). Thus, instructors should develop an appropriate system (relevant to the proposed learning activities) that is associated with key student learning attributes such as collaboration, engagement, and interaction.

\section{Control and monitoring of SM activities}

The SM posts and activities by students and instructors should be managed appropriately and directed in accordance with class learning materials (Bagarukayo 2018; Rambe 2017). Instructors can have higher levels of control (administrators of groups) than students on SM groups, as outlined by Chookaew (2015) so they have full control over the posted content. Hence, instructors should play the role of mentors on platform, 
directing activities for students, and providing them with needed support (Menzies et al. 2017). Control and monitoring are vital to ensure a smooth integration process (Bagarukayo 2018; Chookaew 2015; Menzies et al. 2017; Rambe 2017).

\section{The proposed research framework}

The proposed framework incorporates the identified themes from this study as major components or levels as follows, developing an adoption framework following a sound pedagogical approach (level 1) (Al-Rahmi et al. 2018; Alenazy et al. 2019; Ansari and Khan 2020; Goldie 2016; Musa et al. 2015; Slavin 2014; Mnkandla and Minnaar 2017; Slavin 2014) (Ansari and Khan 2020; Lam 2015). Next, in level 2 and level 3, mitigating challenges associated with SM in education (Alkis et al. 2017; Au and Lam 2015; Chugh and Ruhi 2018; Foroughi 2011; Poore 2015). Then in level 4, developing clear measures and guidance for students, developing incentives to encourage students' participation in the activities, and control and monitoring of activities (Chookaew 2015; De Wever et al. 2015; Menzies et al. 2017; Zheng et al. 2015; Rambe 2017). Lastly in level 5, evaluating the integration process (Al-Rahmi et al. 2018; Foroughi 2011; Zotos and Armakolas 2018). In total, the framework (Fig. 2) includes five levels, in which different aspects of the integration process are addressed adequately.

As shown in Fig. 2, the solid arrows between the framework's levels indicate dependent relationships; hence, levels should be completed in sequential order. Accordingly, components of preceding levels must be fulfilled before initiating the following level.

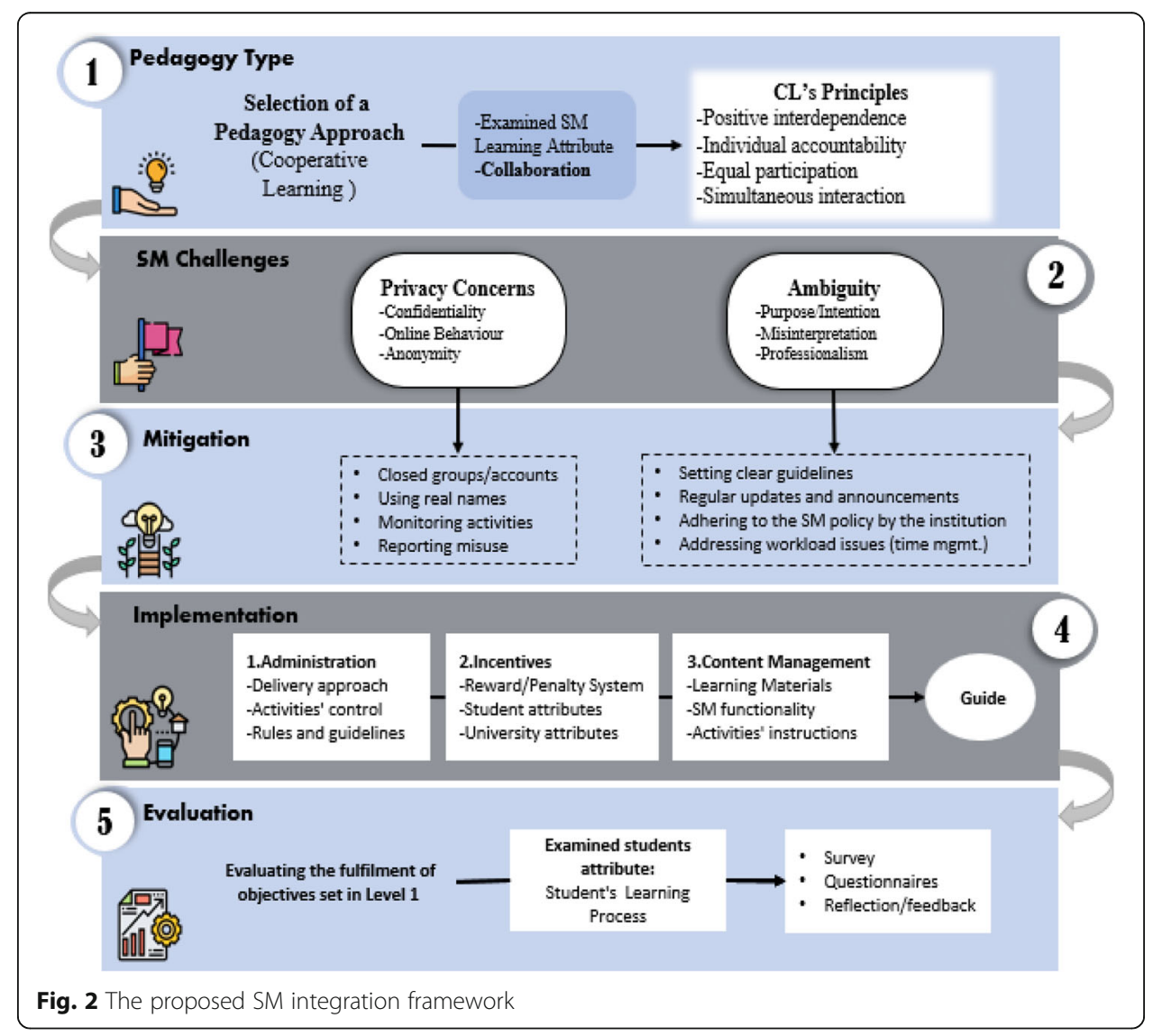


Level 1: Selecting a specific pedagogy type

\section{Pedagogy type}

The first level of the framework (Fig. 2) emphasizes on selecting a specific pedagogy type. The pedagogical approach should be supported by the built-in features and characteristics of the selected SM platform (Slavin 2014). Hence, a SM will be selected based on its attributes such as features, options, and characteristics which can best support the adopted pedagogy type. The framework was developed to address CL pedagogy approach in HE's classrooms; hence, it aims to develop and align SM activities with CL principles to enhance students' overall learning process. The SM activities were adopted from Smith and Waller (1997). The framework supports Formal CL which consists of students working together as part of a group in one subject (Kagan and Kagan 1998), for the duration of an academic semester which is typically distributed on 12-week period.

\section{SM attributes}

Despite having significant similarities in terms of functionality and usability, each SM platform have unique characteristics and features that makes it most effective for specific purposes and under specific settings or contexts (Alenazy et al. 2019). In addition, other traits such as the popularity and ubiquity of the platforms makes them more favored to adopt and use (Brown et al. 2016; Sobaih et al. 2016; Stathopoulou et al. 2019). Hence, it is necessary to examine the selected SM platform's unique attributes prior to the integration process. Accordingly, the platform's attributes should be fit for use to support the adopted pedagogy approach. Common SM platforms that were used by researchers in support of CL are Facebook, Google Groups, and Wikis (Table 3).

\section{SM activities}

In order to structure CL activities effectively through the SM platform, instructors need to understand how to structure positive interdependence, individual accountability, promotive interaction, appropriate use of social skills, and group processing into learning situations. Table 5 presents a summary of SM activities that are promoted by the proposed framework based on CL principles into groups' activities. The identified SM activities were designed to address CL principles explicitly. The activities were adopted from Smith and Waller (1997).

\section{Level 2: Examined SM challenges}

The literature review reveals a manifold of challenges and concerns regarding SM's use for educational purposes, particularly in a HE (Junco and Cotten 2012; Rowan-Kenyon and Alemán 2016; Au and Lam 2015; Chugh and Ruhi 2018; Balakrishnan 2017). It is imperative to address major challenges associated with SM's implementation in HE's classrooms especially privacy and security and ambiguity concerns. Accordingly, the proposed framework aims to mitigate the defined challenges by deploying appropriate measures and initiatives in the integration process.

In $\mathrm{HE}$ environments, privacy on SM is viewed as one of the top challenges for its adoption as an educational tool (Alkis et al. 2017; Au and Lam 2015; Chugh and Ruhi 2018). The proposed framework suggests four major factors that are associated with 
Table 5 SM activities in support of $\mathrm{CL}$

\begin{tabular}{|c|c|}
\hline CL principles & SM activities \\
\hline \multirow[t]{4}{*}{$\begin{array}{l}\text { 1) Positive } \\
\text { interdependence }\end{array}$} & $\begin{array}{l}\text { The focus of the group is on one deliverable (one assignment) to ensure an output } \\
\text { goal interdependence. This will be reflected in the group's name and description on } \\
\text { the platform. }\end{array}$ \\
\hline & $\begin{array}{l}\text { Each member must be able to explain group's submitted deliverable, thus achieving } \\
\text { "Learning goal interdependence" }\end{array}$ \\
\hline & Each member must be assigned a role in the group (role interdependence) \\
\hline & Each member must be assigned a specific part of the assignment to complete \\
\hline \multirow[t]{3}{*}{$\begin{array}{l}\text { 2) Individual } \\
\text { accountability }\end{array}$} & $\begin{array}{l}\text { Individual grades are to be given to group members based on individual tests or } \\
\text { quizzes }\end{array}$ \\
\hline & Use of peer assessments to discourage social loafing \\
\hline & $\begin{array}{l}\text { Each member must label and highlight the part(s) which they have completed in the } \\
\text { deliverable }\end{array}$ \\
\hline \multirow[t]{3}{*}{ 3) Equal participation } & $\begin{array}{l}\text { Assign students with roles that requires them to interact with other members (i.e., } \\
\text { checking writings, proof-reading, keeping records, chairing meetings) }\end{array}$ \\
\hline & $\begin{array}{l}\text { Post progress on the group's discussion page, and follow up using instant messaging } \\
\text { (group chat) }\end{array}$ \\
\hline & $\begin{array}{l}\text { Groups are to be created on the platform as early in the semester, so members can } \\
\text { be familiar with its features and options (they can test all features) }\end{array}$ \\
\hline \multirow[t]{2}{*}{$\begin{array}{l}\text { 4) Simultaneous } \\
\text { interaction }\end{array}$} & $\begin{array}{l}\text { Students' are encouraged to post their reflections, ideas, and opinions in the group } \\
\text { discussion forum to stimulate group discussions }\end{array}$ \\
\hline & $\begin{array}{l}\text { A clear schedule of milestones (meeting and due dates) is to be posted on an } \\
\text { ongoing basis throughout the semester }\end{array}$ \\
\hline
\end{tabular}

mitigating this challenge as follows, confidentiality, online behavior, anonymity, and control and monitoring (discussed thoroughly in the "Level 3: Mitigating the challenges" section). In addition, three major factors associated with the ambiguity challenge and are described below. These factors were reported by recent studies such as Balakrishnan (2017), Fenwick (2016), and Novakovich et al. (2017). The identified factors are addressed thoroughly in level 3 of the framework (the "Level 3: Mitigating the challenges" section).

Purpose/intention: Students may not be aware of the purpose and the intended objectives of integrating SM in their classes.

Professionalism/misinterpretation: Students may only be familiar with SM use for personal purposes and not as a tool for educational purposes. Hence, it is important that they become aware of its professional use in the classroom. Moreover, online bad behavior should not be tolerated on SM accounts designated for classroom learning.

Workload concerns: workload concerns are associated with multitasking, distraction, and time management aspects which may have negative impacts on students' learning process.

\section{Level 3: Mitigating the challenges}

\section{Confidentiality}

Most SM platforms offer personal privacy options which are regularly updated and can be utilized to minimize the challenges associated with confidentiality on the profiles. Majority of SM platforms offer users the option to add a private page or account/profile that is set to private and only accessed by specific users without the need for them to be linked to each other (Rambe 2017; Bagarukayo 2018). 


\section{Online behavior}

Introducing measures to track and monitor online behavior would limit misuse and misconduct by users on selected SM accounts (Chookaew 2015). For example, creating closed groups for approved students to join, monitored by both staff and students, and reporting any misconduct on the group.

\section{Anonymity}

Students must create accounts with their real-life names to gain access to the group.

\section{Ownership}

The group is designed to be part of the T\&L tools of the course unit for the designated period of the semester; hence, it can be closed off and deleted at the end of the semester; all posts and activities on the group can be extracted and saved as archives and records.

\section{Supervision}

The lecturer ultimately supervises the group and acts as an administrator of the group (Zheng et al. 2015). It is also possible to assign a student administrator to report and manage group posts such as students' groupwork exercises (Rambe 2017).

\section{Purpose/intention}

The SM group is to be used only to discuss/share/participate/and engage in learning activities relating to the course unit (Rambe 2017; Menzies et al. 2017).

\section{Professionalism/misinterpretation}

Students must adhere to the SM policy set by the institution (De Wever et al. 2015).

\section{Workload concerns}

Workload concerns are associated with multitasking, distraction, and time management aspects while using the platform (Junco and Cotten 2012; Pearce and Learmonth 2016; Rowan-Kenyon and Alemán 2016). While these aspects can be well governed during face-to-face classrooms, it is rather challenging to control them outside the boundaries of the classroom. Hence, instructors must continually raise awareness among students to minimize the adversities that can be caused by these factors (Zheng et al. 2015). Students need to be made aware of the distraction issue that might result from spending excess time using the SM platform. Links are to be provided via the LMS to the platform's group. In addition, sharing post from other SM platforms is enabled.

\section{Level 4: The implementation process}

\section{Administration}

Instructors or educators seeking to implement SM in classroom teaching, must set clear guidelines for students to know how to access and how to use the SM platform (De Wever et al. 2015; Menzies et al. 2017; Zheng et al. 2015). This would be described in a guide or a worksheet developed by the instructors before the intended date of the implementation. The guide helps students to familiarize themselves with the proposed 
integration process. It includes clear instructions and information on how to access and use the platform, preferably in a workflow style. Instructors should specify the accessibility approach, in which a SM platform can be utilized as a standalone tool or via an existing LMS. The pre-defined guidelines and rules must also cover professionalism aspects and provide examples and templates to clear any misinterpretations that may occur during the conduct of SM activities.

\section{Incentives}

Incentives for SM's use by students for educational purposes are keys to the success of the integration process. Many reviewed academic sources such as Rambe (2017) and Zheng et al. (2015) stressed on the importance of having an unambiguous effective reward system in place to promote and encourage full participations of students in educational SM activities. Although this can be achieved through following a traditional marks-oriented approach such as assessed SM activities, it can further be achieved via other innovative approaches such as score point approach. Nonetheless, a reward system can also be coupled with a penalty system. The inclusion of a reward system alongside the implementation process would motivate students to participate and engage more in the proposed SM learning activities.

\section{Content management}

Managing content of the selected SM platform requires cooperation from instructors and students. Primarily, a selected SM platform is an interactive online resource that can be utilized during designated class time as well as outside class hours. Hence, SM content posted by students and instructors must be managed and directed in accordance with class learning materials and allocated hours to each unit (Greenhow and Burton 2011). Above all, instructors should have higher levels of control than students on content to be posted, shared, or created on the platform (Zheng et al. 2015). Hence, instructors are required to act as mentors of the platform as well as directing activities for students and providing needed support. Nonetheless, instructors should aim to address and achieve identified (level 1) objectives of this process. It is best for them to prepare a clear SM task-activity list to include in their teaching methods based on the features and options enabled by the platform.

A list of major determinants for an effective SM content management plan includes content type (multimedia/videos/pictures/blogs/others), nature (informative/call-for-action/engaging), challenges and risks, consistency and functionality, and usability of selected SM platform. The proposed SM learning activities should have clear instructions that highlight what needs to be accomplished by students while describing the ownership and supervision aspects related to each task or the overall activities.

\section{Level 5: Evaluation}

The final phase is evaluating the overall activities and stages of the integration process. The framework suggests two levels for an effective evaluation process. First, is evaluating the conduct of the stages of the implementation process. Second, is assessing the impact of the integration process on students' learning process. 
Evaluating the stages of the integration process is best achieved by measuring the fulfillment of previously set goals and objectives (level 1). This includes measuring the identified learning outcomes of SM's inclusion against a set of standards and expectations. In addition, assessing SM activities through observation and marking responses of students can aid the overall evaluation process. Hence, it is vital to extensively describe and discuss the anticipated SM learning outcomes earlier in level 1 of the framework to facilitate the evaluation process.

To understand and evaluate the impact of the integration process on the students' learning process, instructors may adopt different approaches such as seeking constructive feedback and reflections such as surveys and questionnaires from students throughout the process or at the conclusion of the process (Al-Rahmi et al. 2018; Foroughi 2011; Zotos and Armakolas 2018). Recent research on students' learning process suggests different tools, methods, and approaches to assess and evaluate this process. Most notable is Biggs et al. (2001)'s revised two factors' study process questionnaire which can be adopted as part of an online questionnaire to be completed by students at the conclusion of the integration process. Nevertheless, limiting instructors to one method of evaluating students' learning process is discouraged given the various constructs that affects their decision-making process such as available resources and ICT skills.

\section{Limitation and future work}

The developed conceptual integration framework (Fig. 2) introduces five levels to effectively integrate $\mathrm{SM}$ in $\mathrm{HE}$ classroom as a CL tool. It focuses on two major challenges in education which are privacy and ambiguity challenges and attempts to mitigate them. Given that the framework is intended to be tested in an Australian university, some challenges relating to integrating SM in developing countries' education sectors may not be relevant to this study. In addition, student learning process is a complex construct and the research may have not captured all the aspects of this construct. Finally, the proposed framework is a conceptual framework that requires further testing and validation through experimental research that produces empirical results. Additional pilot researches are needed to complement the findings of this study. Despite the limitations, the research has important implications for researchers and educators.

\section{Conclusion}

In conclusion, examining the theoretical background for utilizing SM as educational tools in HE was an important step in order to address the research gap in the literature. Accordingly, the paper provided a granular look at SM's pedagogical usage within universities with a focus on $\mathrm{CL}$, thus providing valuable insights on SM's use in education. This paper is a first in this field of study that conducts an integrative review to identify common themes for implementing SM as CL tool in HE. Ultimately, it produced a novel conceptual framework for integrating SM as CL tool in HE. The paper adapts an intuitive inquiry paradigm by integrating six themes identified in the literature review along with findings from the integrative review into an original integration framework.

In summary, the paper investigated the theoretical basis for SM's use as educational tool in education, namely, HE. It concluded the investigation with a list of 
four major theories as follows UGT, TAM, connectivism, and constructivism. Then, a description of SM's pedagogical usage within HE was provided. This study concludes that the use of SM in HE classrooms was predominantly associated with aims to enhance students' collaboration, engagement, and communication. SM's use by universities is also associated with addressing students' changing needs and overall learning goals in HE. The discussion of major literary papers in this field of study was concluded by that SM is primarily being used as part of constructivistbased approaches, namely, CL methods. The paper investigated the use of SM in support of CL in HE's classrooms. Consequently, the paper examined relevant research that proposed SM integration frameworks in educational contexts. The results concluded that SM platforms were adopted to supplement both in-class learning activities as well as offline activities. After a detailed integrative review, the emerged themes were used as basis to develop the proposed SM integration framework. In conclusion, the proposed framework emphasizes SM's potentials as an effective educational tool in HE's classrooms, namely, in support of CL approaches. Thereby, SM can enhance student's learning process if implemented carefully in HE classrooms following CL principles.

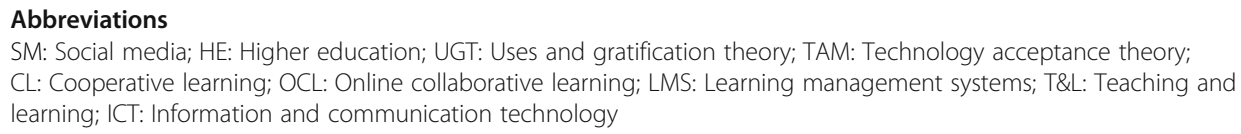

Acknowledgements

Not applicable

\author{
Authors' contributions \\ The first author, Mostafa Hamadi, was the lead in this research. He designed the study, carried out the research \\ methods, performed the analysis, developed the theoretical framework, and wrote the manuscript with support and \\ guidance from supervisors. \\ Dr. Jamal El-Den also contributed to the planning, implementation of the research, contributing to the final manuscript \\ and the discussion of the results as well as supervising the work. \\ Dr. Sami Azam and Dr. Narumon Sriratanaviriyakul (Cherry) were involved in supervising the work as well as \\ contributing to the final manuscript. All authors read and approved the final manuscript.
}

\title{
Authors' information
}

Mr. Mostafa Hamadi is currently a PhD candidate at Charles Darwin University (CDU) in the Area of Information Systems, interests' study areas include Social Computing, SM in Higher Education, HCl, IS, Social Media, and KM. His current research focuses on enhancing the students' learning process through integrating contemporary technologies, namely, social media as educational tools in higher education's learning environments. He is an IT professional with years of experience in IT service management. Mr. Hamadi is ITIL certified and holds an academic certifications and degrees including business certificates. Currently he is a casual lecturer at the College of Engineering, IT, and Environment.

Dr. Jamal El-Den, Charles Darwin University, PhD, Knowledge Management, Knowledge Transformation (tacit vs. explicit), Support for remote interactions, Group support systems. ICT Senior Lecturer - Information Technology, CDU, Darwin, Australia. He was the Chair of the IT Discipline and a Senior Research Fellow at the College of Engineering IT and Environment at Charles Darwin University, Australia. Jamal has 28 years of teaching experiences at tertiary levels. His research interests are in Knowledge Management, Enhancing organizational productivity, Positive Psychology, E-

Commerce, Systems analysis and Design and Group support Systems. His research focuses on the application of KM on different areas of business, such as supply chain management, security compliance, and process development. Dr. El-Den teaches subjects in the areas of Information Systems and Information technology. Dr El-Den has a list of publications on diverse areas of application of IT/IS in business. Dr. El-Den is a Member of ACS.

Dr. SAMI AZAM is currently a leading Researcher and a Lecturer with the College of Engineering and IT, Charles Darwin University, Australia. He is actively involved in the research fields relating to computer vision, signal processing, artificial intelligence, and biomedical engineering. He has a number of publications in peer-reviewed journals and international conference proceedings.

Dr. (Cherry) Narumon Sriratanaviriyakul, Charles Darwin University, PhD, Master, Knowledge Management, Learning and Teaching, Case Methods, Technology in Education, Management Information Systems. ICT Senior Lecturer Information Technology, CDU, Darwin, Australia. Dr. Sriratanaviriyakul (Cherry), is a Member of ACS, holds a PhD in Information Technology from Charles Darwin University. She holds a Master Degree in E-commerce from Assumption University, Thailand. She has been in education for over 14 years at Mahidol University (Thailand), RMIT University (Vietnam), and her major research interests are knowledge management, E-commerce, pedagogical discussion cases 
development, entrepreneurship, case methods in IS education, cyber bullying, and learning and teaching. She is currently a Lecturer at Charles Darwin University teaching in the IS Discipline a variety of units such as Enterprise Management, Entrepreneurship for Professional, and IS practice. She has international experience in teaching and research and she co-authored a book and has many journals and conference publications.

\section{Funding}

Not applicable

Availability of data and materials

Data analysis is included in the corpus of the paper (Table 4). Other materials are not applicable to this research.

\section{Declarations}

\section{Competing interests}

The authors declare that they have no competing interests.

Received: 12 August 2020 Accepted: 19 June 2021

Published online: 21 July 2021

\section{References}

Absar, R., Gruzd, A., Haythornthwaite, C., \& Paulin, D. (2016). Linking online identities and content in connectivist MOOCs across multiple social media platforms. Proceedings of the 25th International Conference Companion on World Wide Web,

Ahern, L., Feller, J., \& Nagle, T. (2016). Social media as a support for learning in universities: An empirical study of Facebook Groups. Journal of Decision Systems, 25(sup1), 35-49. https://doi.org/https://doi.org/10.1080/12460125.2016.1187421,

Akçayır, G. (2017). Why do faculty members use or not use social networking sites for education? Computers in Human Behavior, 71, 378-385. https://doi.org/10.1016/j.chb.2017.02.028.

Alenazy, W. M., Al-Rahmi, W. M., \& Khan, M. S. (2019). Validation of TAM model on social media use for collaborative learning to enhance collaborative authoring. IEEE Access, 7, 71550-71562. https://doi.org/10.1109/ACCESS.2019.2920242.

Alkis, Y., Kadirhan, Z., \& Sat, M. (2017). Development and validation of social anxiety scale for social media users. Computers in Human Behavior, 72, 296-303. https://doi.org/10.1016/j.chb.2017.03.011.

Al-Rahmi, W. M., Alias, N., Othman, M. S., Marin, V. I., \& Tur, G. (2018). A model of factors affecting learning performance through the use of social media in Malaysian higher education. Computers \& Education, 121, 59-72. https://doi.org/10.101 6/j.compedu.2018.02.010.

Al-rahmi, W. M., Othman, M. S., \& Yusuf, L. M. (2015). Social media for collaborative learning and engagement: Adoption framework in higher education institutions in Malaysia. Mediterranean Journal of Social Sciences, 6(3 S1), 246.

Ansari, J. A. N., \& Khan, N. A. (2020). Exploring the role of social media in collaborative learning the new domain of learning. Smart Learning Environments, 7(1), 1-16.

Arif, M., \& Kanwal, S. (2016). Adoption of social media technologies and their impact on students' academic performance: The only way for future survival of distance education students in Pakistan. Pakistan Journal of Information Management and Libraries, 18(1), 25-36. https://doi.org/10.47657/2016181947.

Au, M., \& Lam, J. (2015). Social media education: Barriers and critical issues. In Technology in Education. Transforming educational practices with technology (pp. 199-205). Springer.

Bagarukayo, E. (2018). Social media use to transfer knowledge into practice and aid interaction in higher education. International Journal of Education and Development using ICT, 14(2).

Bahati, B. (2015). Extending student discussions beyond lecture room walls via Facebook. Journal of Education and Practice, $6(15), 160-171$

Balakrishnan, V. (2017). Key determinants for intention to use social media for learning in higher education institutions. Universal access in the information society, 16(2), 289-301. https://doi.org/10.1007/s10209-016-0457-0.

Bereiter, C. (1994). Constructivism, socioculturalism, and Popper's world 3. Educational researcher, 23(7), 21-23. https://doi. org/10.3102/0013189X023007021.

Biggs, J., Kember, D., \& Leung, D. Y. (2001). The revised two-factor study process questionnaire: R-SPQ-2F. British journal of educational psychology, 71(1), 133-149. https://doi.org/10.1348/000709901158433.

Bransford, J. D., Brown, A. L., \& Cocking, R. R. (2000). How people learn, (vol. 11). Washington, DC: National academy press.

Braun, V., \& Clarke, V. (2006). Using thematic analysis in psychology. Qualitative research in psychology, 3(2), 77-101. https://doi. org/10.1191/1478088706qp063oa.

Brown, M. G., Wohn, D. Y., \& Ellison, N. (2016). Without a map: College access and the online practices of youth from lowincome communities. Computers \& Education, 92, 104-116

Chookaew, S. (2015). Using social media-based cooperative learning to enhance pre-service teachers' computer multimedia instruction performance.

Chugh, R., \& Ruhi, U. (2018). Social media in higher education: A literature review of Facebook. Education and Information Technologies, 23(2), 605-616. https://doi.org/10.1007/s10639-017-9621-2.

Chung, C.-J., Lai, C.-L., \& Hwang, G.-J. (2019). Roles and research trends of flipped classrooms in nursing education: A review of academic publications from 2010 to 2017. Interactive Learning Environments, 1-22.

Conway, M., Cao, Y., \& Hong, P. (2011). Antecedents and consequences of social media utilization in college teaching: A proposed model with mixed-methods investigation. On the Horizon.

Corcuera, J. K. B. (2019). Exploring social media as a communication tool for student-athletes and their formators. [GKA EDU 2020] Congreso Internacional de Educación y Aprendizaje,

De Wever, B., Hämäläinen, R., Voet, M., \& Gielen, M. (2015). A wiki task for first-year university students: The effect of scripting students' collaboration. The Internet and Higher Education, 25, 37-44. https://doi.org/10.1016/j.iheduc.2014.12.002. 
Deutsch, M. (1949). A theory of co-operation and competition. Human relations, 2(2), 129-152. https://doi.org/10.1177/001872 674900200204.

Dyson, B., \& Casey, A. (2016). Cooperative learning in physical education and physical activity: A practical introduction. Routledge. https://doi.org/10.4324/9781315739496

Fenwick, T. (2016). Social media, professionalism and higher education: A sociomaterial consideration. Studies in Higher Education, 41(4), 664-677. https://doi.org/10.1080/03075079.2014.942275.

Foroughi, A. (2011). A research framework for evaluating the effectiveness of implementations of social media in higher education. Online Journal for Workforce Education and Development, 5(1), 5.

Freeman, S., Eddy, S. L., McDonough, M., Smith, M. K., Okoroafor, N., Jordt, H., \& Wenderoth, M. P. (2014). Active learning increases student performance in science, engineering, and mathematics. Proceedings of the National Academy of Sciences, 111(23), 8410-8415. https://doi.org/10.1073/pnas.1319030111.

Gersten, R., Fuchs, L. S., Compton, D., Coyne, M., Greenwood, C., \& Innocenti, M. S. (2005). Quality indicators for group experimental and quasi-experimental research in special education. Exceptional children, 71(2), 149-164. https://doi.org/1 $0.1177 / 001440290507100202$

Goldie, J. G. S. (2016). Connectivism: A knowledge learning theory for the digital age? Medical teacher, 38(10), 1064-1069. https://doi.org/10.3109/0142159X.2016.1173661.

Greenhow, C., \& Burton, L. (2011). Help from my "friends": Social capital in the social network sites of low-income students. Journal of Educational Computing Research, 45(2), 223-245. https://doi.org/10.2190/EC.45.2.f.

Gruzd, A., Haythornthwaite, C., Paulin, D., Gilbert, S., \& Del Valle, M. E. (2018). Uses and gratifications factors for social media use in teaching: Instructors' perspectives. New Media \& Society, 20(2), 475-494. https://doi.org/10.1177/1461444816662933.

Harasim, L. (2012). Introduction to learning theory and technology, Chapter 1. Learning Theory and Online Technologies.

Harran, M., \& Olamijulo, C. (2014). Social media communication spaces to develop literacies in a higher education language classroom context. South African Journal of Higher Education, 28(2), 410-435.

Hein, G. (1991). Constructivist learning theory. Institute for Inquiry. Available at:https://www.exploratorium.edu/ifi/resources/ constructivistlearning.html.

Johnson, D. W., Johnson, R. T., Holubec, E. J., \& Holubec, E. J. (1994). The new circles of learning: Cooperation in the classroom and school. ASCD.

Junco, R. (2012). Too much face and not enough books: The relationship between multiple indices of Facebook use and academic performance. Computers in Human Behavior, 28(1), 187-198. https://doi.org/10.1016/j.chb.2011.08.026.

Junco, R., \& Cotten, S. R. (2012). No A 4 U: The relationship between multitasking and academic performance. Computers \& Education, 59(2), 505-514. https://doi.org/10.1016/j.compedu.2011.12.023.

Kagan, S., \& Kagan, M. (1998). Staff development and the structural approach to cooperative learning. Professional development for cooperative learning: Issues and approaches, 103-121.

Kaplan, A. M., \& Haenlein, M. (2016). Higher education and the digital revolution: About MOOCs, SPOCs, social media, and the Cookie Monster. Business Horizons, 59(4), 441-450. https://doi.org/10.1016/j.bushor.2016.03.008.

Karau, S. J., \& Williams, K. D. (1993). Social loafing: A meta-analytic review and theoretical integration. Journal of personality and social psychology, 65(4), 681-706. https://doi.org/10.1037/0022-3514.65.4.681.

Kebble, P. G. (2017). Assessing online asynchronous communication strategies designed to enhance large student cohort engagement and foster a community of learning. Journal of Education and Training Studies, 5(8), 92-100. https://doi.org/1 $0.11114 /$ jets.v5i8.2539.

Kivunja, C. (2014). Do you want your students to be job-ready with 21 st century skills? Change pedagogies: A pedagogical paradigm shift from Vygotskyian social constructivism to critical thinking, problem solving and Siemens' digital connectivism. International Journal of Higher Education, 3(3), 81-91.

Lam, J. (2015). Collaborative learning using social media tools in a blended learning course. International conference on hybrid learning and continuing education, Collaborative Learning Using Social Media Tools in a Blended Learning Course,

Lewin, K. (1938). A dynamic theory of personality.(1935). New York and London: Mc Grow Hill Book Company.

Liburd, J. J., \& Christensen, I.-M. F. (2013). Using web 2.0 in higher tourism education. Journal of Hospitality, Leisure, Sport \& Tourism Education, 12(1), 99-108. https://doi.org/10.1016/j.jhlste.2012.09.002.

Menzies, R., Petrie, K., \& Zarb, M. (2017). A case study of Facebook use: Outlining a multi-layer strategy for higher education. Education and information technologies, 22(1), 39-53. https://doi.org/10.1007/s10639-015-9436-y.

Mnkandla, E., \& Minnaar, A. (2017). The use of social media in e-learning: A metasynthesis. International Review of Research in Open and Distributed Learning: IRRODL, 18(5), 227-248.

Moher, D., Shamseer, L., Clarke, M., Ghersi, D., Liberati, A., Petticrew, M., ... Stewart, L. A. (2015). Preferred reporting items for systematic review and meta-analysis protocols (PRISMA-P) 2015 statement. Systematic reviews, 4(1), 1. https://doi.org/10.11 86/2046-4053-4-1.

Musa, A. S., Azmi, M. N. L., \& Ismail, N. S. (2015). Exploring the uses and gratifications theory in the use of social media among the students of mass communication in Nigeria. Malaysian Journal of Distance Education, 17(2), 83-95.

Novakovich, J., Miah, S., \& Shaw, S. (2017). Designing curriculum to shape professional social media skills and identity in virtual communities of practice. Computers \& Education, 104, 65-90. https://doi.org/10.1016/j.compedu.2016.11.002.

Pearce, N., \& Learmonth, S. (2016). Challenges and opportunities in using Facebook to build a community for students at a UK university. In Widening participation, higher education and non-traditional students (pp. 105-117). Springer.

Poore, M. (2015). Using social media in the classroom: A best practice guide. Sage.

Rahman, S., Ramakrishnan, T., \& Ngamassi, L. (2020). Impact of social media use on student satisfaction in Higher Education. Higher Education Quarterly, 74(3), 304-319. https://doi.org/10.1111/hequ.12228.

Rambe, P. (2017). Spaces for interactive engagement or technology for differential academic participation? Google Groups for collaborative learning at a South African University. Journal of Computing in Higher Education, 29(2), 353-387. https://doi. org/10.1007/s12528-017-9141-5.

Ripiye, P.-R., Bacon, L., Mackinnon, L., \& Walker, S. (2017). The use of social media in MOOCs: A review of literature. ECSM 2017 4th European Conference on Social Media. 
Rosenberg, J., Akcaoglu, M., Willet, K. B. S., Greenhalgh, S., \& Koehler, M. (2017). A tale of two Twitters: Synchronous and asynchronous use of the same hashtag. In Society for Information Technology \& Teacher Education International Conference (pp. 283-286). Association for the Advancement of Computing in Education (AACE).

Rowan-Kenyon, H. T., \& Alemán, A. M. M. (2016). Social media in higher education: ASHE higher education report, Volume 42, Number 5. John Wiley \& Sons.

Scager, K., Boonstra, J., Peeters, T., Vulperhorst, J., \& Wiegant, F. (2016). Collaborative learning in higher education: Evoking positive interdependence. CBE-Life Sciences Education, 15(4), ar69.

Slavin, R. E. (2014). Cooperative learning and academic achievement: Why does groupwork work?. [Aprendizaje cooperativo y rendimiento académico: ¿ por qué funciona el trabajo en grupo?]. Anales de Psicología/Annals of Psychology, 30(3), $785-791$.

Smith, K. A., \& Waller, A. A. (1997). Cooperative learning for new college teachers. New paradigms for college teaching, 185-209.

Sobaih, A. E. E., Moustafa, M. A., Ghandforoush, P., \& Khan, M. (2016). To use or not to use? Social media in higher education in developing countries. Computers in Human Behavior, 58, 296-305. https://doi.org/10.1016/j.chb.2016.01.002.

Stathopoulou, A., Siamagka, N.-T., \& Christodoulides, G. (2019). A multi-stakeholder view of social media as a supporting tool in higher education: An educator-student perspective. European Management Journal, 37(4), 421-431. https://doi.org/10.1 016/j.emj.2019.01.008.

Whittemore, R., \& Knafl, K. (2005). The integrative review: Updated methodology. Journal of advanced nursing, 52(5), 546-553. https://doi.org/10.1111/j.1365-2648.2005.03621.x.

Zheng, B., Niiya, M., \& Warschauer, M. (2015). Wikis and collaborative learning in higher education. Technology, Pedagogy and Education, 24(3), 357-374. https://doi.org/10.1080/1475939X.2014.948041.

Zotos, C., \& Armakolas, S. (2018). The role of social media in education: Designing a novel digital learning environment.

\section{Publisher's Note}

Springer Nature remains neutral with regard to jurisdictional claims in published maps and institutional affiliations.

\section{Submit your manuscript to a SpringerOpen ${ }^{\circ}$ journal and benefit from:}

- Convenient online submission

$\checkmark$ Rigorous peer review

- Open access: articles freely available online

- High visibility within the field

- Retaining the copyright to your article

Submit your next manuscript at $\boldsymbol{\Delta}$ springeropen.com 